\title{
E-Learning and Understanding of Accounting During Covid-19 Pandemic
}

\author{
Sigit Hermawan ${ }^{1 *}$, Nur Ravita Hanun², Anita Fitria Jannah³ ${ }^{3}$ Mochammad Ilyas Junjunan ${ }^{4}$ \\ 1,2,3 Universitas Muhammadiyah Sidoarjo, East Java, Indonesia \\ ${ }^{4}$ Universitas Islam Negeri Sunan Ampel Surabaya, East Java, Indonesia
}

\section{A R T I C L E I N F O \\ Article history: \\ Received 07 January 2021 \\ Received in revised form \\ 15 January 2021 \\ Accepted 03 February 2021 \\ Available online 25 \\ February 2021}

Keywords:

E-Learning; Accounting;

Covid-19 Pandemic

\begin{abstract}
A B S T R A C T
Covid-19 Pandemic has taken place throughout the world and has changed the whole structure of life including the fields of business education and accounting. This study was designed to analyze various factors that cause accounting understanding in the Covid-19 Pandemic. Some of these factors are emotional intelligence, availability of technological facilities, and implementation of e learning. The study was conducted during the Covid-19 Pandemic period, namely in April and May 2020 by distributing questionnaires to accounting students amounting to 194 as a research sample. Based on the results of the study, Emotional Intelligence and E-Learning implementation affect accounting understanding. However, the availability of information technology partially has no effect on the understanding of its accounting. With the results of this study will have implications for various policies related to learning in business and accounting during the Covid-19 Pandemic, especially on the availability of information technology and implementation of e learning.
\end{abstract}

Copyright (C) Universitas Pendidikan Ganesha. All rights reserved.

\section{Introduction}

The existence of coronavirus or covid-19 has changed the whole order of life including in the fields of education. As part of the effort to contain the spread of the coronavirus, public spaces such as schools, universities, and offices are closing down so people can stay at home and prevent further spread. Stay at home and learning from home is a way to break the Covid-19 Pandemic chain but still be able to carry out the learning process. Various learning methods are carried out so that learning objectives can still be achieved, including one of them is e-learning. With the existence of e-learning, it is expected that the learning process will continue and not have an impact on student understanding (Almarzooq et al., 2020; Creţan \& Light, 2020; Heyang \& Martin, 2020; Kapasia et al., 2020; Krishnamurthy, 2020; Mhlanga \& Moloi, 2020; Moorhouse, 2020; Nguyen et al., 2020; Ritter \& Pedersen, 2020; Xue et al., 2020).

Implementation of lectures with e learning is closely related to student understanding. Moreover, lectures on e-learning during the Covid-19 Pandemic event were carried out in full. This means that there are no lectures in class and meet with lecturers so that students need independence to study. The existence of e learning also requires the availability of information technology that supports the smooth learning process. Information technology related to internet networks and also the use of these networks (Favale et al., 2020; Gel et al., 2014). Implementation of e learning for one full semester requires emotional intelligence because it is associated with movement, self-control, and self-recognition (Moorhouse, 2020). Because learning from home really makes students bored so they need more motivation to be able to do it. Especially if there are tasks that must be done either individual or group tasks. 
As explained earlier that e learning is very related to the understanding of students including accounting students. An understanding of accounting is measured by how a student understands what has been learned at this time. Not only the value obtained but also can be seen if students understand and master the knowledge they have gained along with their concepts. Nowadays there are many people with higher education but their careers are hampered. Most education programs are only IQ-centered. Yet what is needed is one's ability to control emotions, self-discipline, able to motivate oneself, able to control oneself when depressed, able to empathize with others (Malan, 2020; Marzuki et al., 2020; Rinaldi et al., 2020)

Factors that can affect a persons' success besides cognitive intelligence are emotional intelligence. According to Moorhouse (2020) believes emotional intelligence is a person's ability to motivate himself, rise to face weaknesses, can manage moods and manage himself so that he can continue to think, empathize, and pray. Another factor used to study understanding of accounting courses is the availability of information technology. In following the development of information technology, the role of science is very important that makes human resources capable and competent. Venkatesh (2003) discusses that information technology is a tool used to obtain and store data, process and process data, and manipulate data in various ways to obtain quality information. The next factor that can influence accounting understanding is the use of instructional media. E-learning is one of the learning media models that the government is currently activating. E-Learning is learning that utilizes information and communication technology, namely the internet network. E-Learning facilitates interaction between lecturers and students without the need for classroom learning.

The COVID-19 pandemic urges universities in Indonesia to accelerate the adjustment of the learning process using alternative methods.The application of e-learning cannot be avoided from situations and conditions during a pandemic (Moorhouse, 2020). Even though the application of elearning has been well optimized, there are several factors that will become obstacles so that the application of e-learning becomes ineffective as a distance learning process (Chan \& Ngai, 2012).Human resources and the availability of information technology are the main factors for the successful implementation of e-learning (Smith \& Mitry, 2008; Xiangqian \& Fuqing, 2012). In addition, the level of difficulty of the course is another determining factor for the success of online learning (Halawi et al., 2009). However, in fact, the application of e-learning has not been felt equally by students because of the disparity between students living in urban and rural areas.Meanwhile, students with an exact science base have more difficulty accepting the application of e-learning compared to students based on social science.

The basic theories that are appropriate for this research are intelligent theory and Technology Acceptance Model (TAM). To measure students' understanding in accounting, TAM is used in this study. TAM is one of the first models that combines human cognitive factors that can influence the acceptance of technology in various jobs (Davis, 1989), and is a theoretical approach that models the process of acceptance and use of new technology by various groups (Davis et al., 1989). The TAM model was first introduced by Fishbein \& Azjen (1975) as a theory of rooted action designed to analyze and anticipate intentions and predict a person's behavior based on factors such as attitudes and subjective norms that refer to belief without motivation.

There are two variables forming TAM, namely perceived usefulness and perceived ease of use (Davis et al., 1989). Perceived benefits are the level of user confidence that using information technology will improve their performance. Intelligence is defined as a person's ability to accept something new and be able to learn from the experiences of others in the past (Teo, 2012; Walker et al., 2020). In addition, the TAM model also provides research contributions related to the use of information technology in the era of the industrial revolution 4.0 (Hu et al., 1999; Shin, 2009; Svendsen et al., 2013; Taherdoost, 2018; Wentzel et al., 2013).

Pavel, et al (2015) states that emotional intelligence is one's ability to control oneself and regulate moods under certain circumstances. Able to deal with failure, control emotions and regulate the state of self. Referring to research conducted by Rinaldi, et al (2020) which shows that emotional intelligence which includes self-recognition, self-control, motivation, empathy, social skills has a positive and significant effect on the level of accounting understanding. So that the higher the emotional intelligence, the higher the understanding of student accounting. Research of Nahapiet \& Ghoshal (2009) also states the same thing that emotional intelligence affects accounting understanding.H1. Emotional Intelligence influences the understanding of accounting. Availability of Information Technology and Accounting Understanding.

The availability of information technology can be defined as the existence of technology used to obtain data, process data, process data, and store data to produce quality, relevant and accurate data. With the existence of technology, students can access various sources regarding the subject matter being studied. Referring to the results of research Marzuki, et al (2020) which states that the availability of 
technology influences the understanding of accounting. Many students give a positive attitude towards the use of information technology especially the internet as learning in lectures. Such is the case with the results of research by Talebian et al (2014) which states that the availability of information technology influences the understanding of courses.

E-learning can be interpreted as an online learning media that utilizes the internet in its use. Elearning facilitates interaction between students and lecturers. Lecturers can place teaching materials online that can be downloaded by students and assignments to students. Favale, et al (2020) which states that the application of e-learning has a significant effect on student understanding. Furthermore, research of Moore, et al (2011) states that the use of e-learning has an effect on student achievement. H3. E Learning Influences the Understanding of Accounting.

The purpose of this study is to examine the effect of emotional intelligence, the availability of information technology and the application of e-learning to understanding accounting. This study was designed to analyze various factors that cause accounting understanding in the Covid-19 Pandemic. some of these factors are emotional intelligence, availability of technological facilities, and implementation of e learning.

\section{Methods}

This research approach uses a quantitative approach that focuses on hypothesis testing Hermawan \& Amirullah (2016) because the purpose of this study itself is to prove the influence of emotional intelligence, the availability of information technology, and the application of e-learning to accounting understanding.

This research involves 4 (four) variables consisting of 1 (one) dependent variable, namely Accounting Understanding and 3 (three) independent variables, namely Emotional Intelligence, Availability of Information Technology and Application of E-learning.

Table 1. Variable Identification

\begin{tabular}{|c|c|c|c|}
\hline No & Variable & Indicator & Source \\
\hline 1 & $\begin{array}{l}\text { Emotional } \\
\text { Intelligence (X1) }\end{array}$ & $\begin{array}{l}\text { a. Self-introduction } \\
\text { b. Self-control } \\
\text { c. Motivation } \\
\text { d. Empathy } \\
\text { e. Social skills }\end{array}$ & Pavel, et al (2015) \\
\hline 2 & $\begin{array}{l}\text { Availability of } \\
\text { Information } \\
\text { Technology (X2) }\end{array}$ & $\begin{array}{l}\text { a. Internet Network } \\
\text { b. Network Utilization }\end{array}$ & $\begin{array}{l}\text { Marzuki (2020) } \\
\text { Talebian et al,. (2014) }\end{array}$ \\
\hline 3 & $\begin{array}{l}\text { Application of E- } \\
\text { Learning (X3) }\end{array}$ & $\begin{array}{l}\text { a. Readiness in using e-learning } \\
\text { b. Make use of material } \\
\text { c. Make use of tasks } \\
\text { d. Utilization of discussion forums } \\
\text { e. The use of chat } \\
\text { f. Response to learning }\end{array}$ & $\begin{array}{l}\text { Moore, et al (2011) } \\
\text { Favale, et al (2020) }\end{array}$ \\
\hline 4 & $\begin{array}{l}\text { Understanding of } \\
\text { Accounting }\end{array}$ & $\begin{array}{l}\text { a. Intermediate Financial Accounting II } \\
\text { b. Management information System } \\
\text { c. Financial Statement Analysis } \\
\text { d. Advanced Financial Accounting I } \\
\text { e. Management Accounting }\end{array}$ & Malan (2020) \\
\hline
\end{tabular}

The population used in this study were students of the Accounting Study Program Faculty of Business Law and Social Sciences University Muhammadiyah Sidoarjo which amounted to 205 students. While the sample used in this study was selected using the purposive sampling method to obtain 194 students.The lecture was carried out during the Covid-19 Pandemic in April - May 2020. Researchers distributed questionnaires via Google Form using social media assistance such as email and WhatsApp.

Validity test is done with the aim to find out whether or not an item or a variable is valid. The variable of an item or variable is known by comparing the corrected-item-total correlation obtained or 
calculating with 0.30 (alphacrobach), so each question is said to be valid against the indicator. Decision making in the reliability test when the variable is said to be good or significant is positive if it has a value of Crounbach's Alpha> 0.60. This study uses multiple linear regression which is to determine the relationship between variables that are assessed as independent variables with the dependent variable that involves more than two variables. The following calculation formula for multiple linear regression analysis:

$\mathrm{Y}=\mathrm{a}+\mathrm{b} 1 \mathrm{X} 1+\mathrm{b} 2 \mathrm{X} 2+\mathrm{b} 3 \mathrm{X} 3+\mathrm{e}$

\section{Results and Discussions}

\section{Results}

Table 2 explains the results of the hypothesis test ( $t$ test). In this hypothesis test using the test is used to measure the level of influence of significance between independent variables on the dependent variable. From the results of calculations using SPSS software version 18 in the Coefficients table, the value of the Emotional Intelligence variable is 4.507, the Availability of Information Technology is 0.330 and the application of E-learning is 6.763. The t test is as follows: With $\mathrm{df}=\mathrm{n}-\mathrm{k}=182-4=178$ to obtain a table of 1.973. Based on the test can be explained as follows:

Based on the results of the $t$ test conducted on the variable Emotional Intelligence (X1), the value of $t$ is 4.507. Therefore, the value of this $t$ count is greater than the table value of 1.973 . The significance value obtained was $0,000<0.05$. Because ( $t$ count $>t$ table $=4,507>1,973$ ) and $(\operatorname{sig}<\alpha=0,000<0,05)$ then $\mathrm{HO}$ is rejected and $\mathrm{Ha}$ is accepted, meaning that there is an influence of Emotional Intelligence (X1) on Accounting Understanding $(\mathrm{Y})$.

Based on the results of the test carried out on the variable Information Technology Availability (X2) obtained t count value of 0.330 . Therefore, the t-count value is smaller than the t table value of 1.973. The significance value obtained was $0.742>0.05$. Because ( $\mathrm{t}$ count $<\mathrm{t}$ table $=0.330<1.973$ ) and (sig $>\alpha=$ $0.742>0.05$ ) then $\mathrm{HO}$ is accepted and $\mathrm{Ha}$ is rejected. This means that there is no effect of Information Technology Availability (X2) on Accounting Understanding (Y).

Based on the results of the $t$ test carried out on the variable Implementation of E-learning (X3) obtained a t count of 6.763. Therefore, the value of this t count is greater than the table value of 1.973 . The significance value obtained was $0,000<0.05$. Because ( $t$ count $>t$ table $=6,763>1,973$ ) and $(\operatorname{sig}<\alpha=0,000$ $<0,05)$ then Ho is rejected and $\mathrm{Ha}$ is accepted, meaning that there is an influence of the Application of $\mathrm{E}$ learning (X3) on Accounting Understanding (Y).

Table 2. T Test Results

\begin{tabular}{lccc}
\hline \multirow{2}{*}{ Model } & \multicolumn{1}{c}{ Coefficiencts } & Sig. \\
\cline { 2 - 4 } & $\begin{array}{c}\text { Unstandardized } \\
\text { Coefficients (B) }\end{array}$ & $\mathbf{t}$ & 0.000 \\
\hline $\begin{array}{l}\text { (Constant) } \\
\begin{array}{l}\text { Emotional Intelligence } \\
\left(\mathrm{X}_{1}\right)\end{array}\end{array}$ & 19.518 & 4.638 & 0.000 \\
$\begin{array}{l}\text { Availability } \\
\text { Information } \\
\text { Technology (X) }\end{array}$ & 0.411 & 0.330 & 0.742 \\
$\begin{array}{l}\text { Application of E- } \\
\text { learning }\left(\mathrm{X}_{3}\right)\end{array}$ & 0.050 & 6.763 & 0.000 \\
\hline
\end{tabular}

Dependent variable: Understanding of Accounting (Y)

\section{Discussions}

The results of this study indicate that the variable Emotional Intelligence is obtained with a significance level of $0,000<0.05$ then $\mathrm{H} 1$ is accepted. This means that emotional intelligence has a positive and significant effect on accounting understanding in Accounting Students at Universitas Muhammadiyah Sidoarjo in Covid-19 pandemic. This means that with the better application of emotional intelligence, understanding of accounting will also increase. In connection with the results of this study with Covid-19 Pandemic that accounting students Universitas Muhammadiyah Sidoarjo have good emotional intelligence. This means that students remain motivated to conduct lectures with e learning and learning from home systems. Students can also control themselves with assignments given by the lecturer and do it even though they cannot meet directly with their friends. 
Furthermore, this research supports intelligence theory. Intelligence consists of three components, namely the ability to direct thoughts or direct actions, the ability to change the course of action when the action has been carried out, the ability to criticize oneself. Emotional intelligence is the ability of someone who is used to recognize and control feelings to help the mind, control and understand oneself and others in managing emotions in everyday life. In lectures emotional intelligence is also needed in everything that involves interaction in a lecture. Based on the theory conveyed by Pavel, et al (2015) emotional intelligence of students has an influence on student achievement. Emotional intelligence is able to train the ability to manage their feelings, the ability to deal with stress, the ability to motivate themselves, the ability to drive and postpone the satisfaction of a moment, set a reactive mood and be able to empathize and cooperate with others. These research results are consistent with Nahapiet \& Ghoshal (2009) research stating that the variable Emotional Intelligence has a significant effect on Accounting Understanding. Similarly, Rinaldi, et al (2020) shows that Emotional Intelligence has a significant effect on Accounting Understanding. However, this study is not in line with the results of research conducted by Gel, et al (2014) showing that Emotional Intelligence has a negative effect on accounting understanding but the effect is not significant.

Meanwhile, the value of the information technology availability variable indicates a significant level of $0.742>0.05$ then $\mathrm{H} 2$ is rejected. This means that the availability of Information Technology has no effect on Accounting Understanding at Accounting Students of Universitas Muhammadiyah Sidoarjo in Covid-19 pandemic. The availability of information technology in this study does not affect accounting understanding because there are several factors. First is the internet network. Lectures with e-learning require a stable internet network. This means that students must have a strong internet data package. This is what often makes students feel heavy with e learning lectures. This is what causes students to not have the ability to understand accounting because students often have problems with the internet network. The second is related to accounting students at Universitas Muhammadiyah Sidoarjo, most of whom are nonregular students (student workers or employees). Students with employee status do not have enough time to be able to study so that it affects accounting understanding. Especially during this Covid-19 pandemic, each lecturer gave a lot of assignments so that the time was taken up to do the assignment. Furthermore, this result is consistent with Xue, et al (2020) research which shows that the availability of information technology has no effect on student understanding. However, these results are not in line with research conducted by Venkatesh, et al (2003) which shows that the availability of Information Technology has a significant and significant effect on accounting understanding.

Meanwhile, the e-learning implementation variable shows that the e-learning implementation variable is obtained with a significant level of $0,000<0.05$ then $\mathrm{H} 3$ is accepted. This means that the application of e-learning has a significant influence on Accounting Understanding at Accounting Students of Universitas Muhammadiyah Sidoarjo. Based on the results of this study means the learning management policy during the Covid-19 Pandemic through e learning is appropriate. That is because the facilities in the e learning module are quite complete and the data is stored in the application. Like the Moodle e learning type used by Universitas Muhammadiyah Sidoarjo has many facilities that can be used as interactions between lecturers and students, such as forums, chat, quizzes, feedback and others. For the midterm and final semester exams, it can also be done through this Moodle e learning facility. With the various facilities available in e learning makes students have a good understanding of accounting.

The research of results supports the basic theory of Technology Acceptance Model (TAM). There are two forming variables of TAM, which are perceived usefulness and perceived ease of use. The TAM model is adopted from the Theory Reasoned Action (TRA) model developed by Fishbein \& Azjen (1975) with an assumption that the reactions and perceptions of individuals will determine their attitudes and behaviour towards information technology. Behavioural aspects in the adoption of information technology is an important thing to note, because the interaction between users with computer devices is the result of the influence of perceptions, attitudes that exist in individuals. These research results are consistent with research by Sun, et al (2008) which states that the application of e-learning has a significant and significant effect on student activity. This is in line with research of Moore, et al (2011) which shows that the use of e-learning has a significant and significant effect on student achievement.

\section{Conclusion}

Based on the results and discussion, it can be concluded that students have the motivation to learn with the e-learning system during the COVID-19 pandemic. Students can control themselves over the assignments given by the lecturer, and students do assignments independently or in groups from home even though they cannot meet directly with friends. In addition, a good campus e-learning application will determine the understanding of courses in accounting. Campus policies that emphasize e-learning appear 
to be very appropriate in the era of COVID-19. This is because the level of readiness of the campus in implementing e-learning is quite good, where there are facilities such as e-modules and e-learning applications that are easy to use.

However, the availability of technology and information in this study has not shown an effect on the level of understanding of accounting students. The variety of student living locations causes differences in internet network signals for each student to be the main reason students fail to understand accounting when e-learning is implemented. The learning achievement of accounting subjects which tends to be applicative and implementative is another reason that the availability of technology and information cannot affect the level of understanding of accounting students.

\section{References}

Almarzooq, Z. I., Lopes, M., \& Kochar, A. (2020). Virtual Learning During the COVID-19 Pandemic: A Disruptive Technology in Graduate Medical Education. Journal of the American College of Cardiology, 75(20), 2635-2638. https://doi.org/10.1016/j.jacc.2020.04.015.

Chan, S. C. H., \& Ngai, E. W. T. (2012). Electronic Learning Systems in Hong Kong Business Organizations: A Study of Early and Late Adopters. Journal of Education for Business, 87(3), 170-177. https://doi.org/10.1080/08832323.2011.586005.

Creţan, R., \& Light, D. (2020). COVID-19 in Romania: transnational labour, geopolitics, and the Roma 'outsiders.' Eurasian Geography and Economics, 00(00), 1-14. https://doi.org/10.1080/15387216.2020.1780929.

Davis, F. D. (1989). Perceived Usefulness, Perceived Ease of Use, and User Acceptance of Information Technology. Management Information Systems Research Center, 13(3), 319-340. https://doi.org/10.5962/bhl.title.33621.

Davis, F. D., Bagozzi, R. P., \& Warshaw, P. R. (1989). User Acceptance of Computer Technology: A Comparison of Two Theoretical Models. Management Science, 35(8), 982-1003. https://doi.org/10.1287/mnsc.35.8.982.

Favale, T., Soro, F., Trevisan, M., Drago, I., \& Mellia, M. (2020). Campus traffic and e-Learning during COVID-19 pandemic. $\quad$ Computer Networks, https://doi.org/10.1016/j.comnet.2020.107290.

Fishbein, M., \& Azjen, I. (1975). Belief, Attitude, Intention, and Behavior: An Introduction to Theory and Research. Reading, MA: Addison-Wesley. Contemporary Sociology, 6(2), 244-245.

Gel, Y. R., O’Hara Hines, R. J., Chen, H., Noguchi, K., \& Schoner, V. (2014). Developing and Assessing ELearning Techniques for Teaching Forecasting. Journal of Education for Business, 89(5), 215-221. https://doi.org/10.1080/08832323.2013.856281.

Halawi, L. A., McCarthy, R. V., \& Pires, S. (2009). An Evaluation of E-Learning on the Basis of Bloom's Taxonomy: An Exploratory Study. Journal of Education for Business, 84(6), 374-380. https://doi.org/10.3200/JOEB.84.6.374-380.

Hermawan, S., \& Amirullah. (2016). Metode Penelitian Bisnis Pendekatan Kuantitatif dan Kualitatif. Media Nusa Creative.

Heyang, T., \& Martin, R. (2020). A reimagined world: international tertiary dance education in light of COVID-19. Research in Dance Education, 00(00), 1-15. https: //doi.org/10.1080/14647893.2020.1780206.

Hu, P. J., Chau, P. Y. K., Liu Sheng, O. R., \& Tam, K. Y. (1999). Examining the Technology Acceptance Model Using Physician Acceptance of Telemedicine Technology. Journal of Management Information Systems, 16(2), 91-112. https://doi.org/10.1080/07421222.1999.11518247.

Kapasia, N., Paul, P., Roy, A., Saha, J., Zaveri, A., Mallick, R., Barman, B., Das, P., \& Chouhan, P. (2020). Impact of lockdown on learning status of undergraduate and postgraduate students during COVID-19 pandemic in West Bengal, India. Children and Youth Services Review, 116(June), 105194. https://doi.org/10.1016/j.childyouth.2020.105194.

Krishnamurthy, S. (2020). The future of business education: A commentary in the shadow of the Covid-19 pandemic. Journal of Business Research, 117(May), 1-5. 
https://doi.org/10.1016/j.jbusres.2020.05.034.

Malan, M. (2020). Engaging students in a fully online accounting degree: an action research study. Accounting Education, 1-19. https://doi.org/10.1080/09639284.2020.1787855.

Marzuki, M. M., Majid, W. Z. N. A., Shukri, R. S. M., Zawawi, M. Z. M., \& Bakar, H. A. (2020). 4P-Model of accounting learning process: The role of mobile apps technology among non-accounting students. Journal of Education for Business, 95(6), 384-392. https://doi.org/10.1080/08832323.2019.1666787.

Mhlanga, D., \& Moloi, T. (2020). COVID-19 and the digital transformation of education: What we are learning in South Africa. Not Peer Reviewed, April, 1-13. https://doi.org/10.20944/preprints202004.0195.v1.

Moore, J. L., Dickson-Deane, C., \& Galyen, K. (2011). E-Learning, online learning, and distance learning environments: Are they the same? Internet and Higher Education. https://doi.org/10.1016/j.iheduc.2010.10.001.

Moorhouse, B. L. (2020). Adaptations to a face-to-face initial teacher education course 'forced' online due to the COVID-19 pandemic. Journal of Education for Teaching, 00(00), 1-3. https://doi.org/10.1080/02607476.2020.1755205.

Nahapiet, J., \& Ghoshal, S. (2009). Social capital, intellectual capital, and the organizational advantage. In Knowledge and Social Capital. https://doi.org/10.2307/259373.

Nguyen, K. D., Enos, T., Vandergriff, T., Vasquez, R., Cruz, P. D., Jacobe, H. T., \& Mauskar, M. M. (2020). Opportunities for education during the COVID-19 pandemic. JAAD International, 1(1), 21-22. https://doi.org/10.1016/j.jdin.2020.04.003.

Pavel, A.-P., Fruth, A., \& Neacsu, M.-N. (2015). ICT and E-Learning - Catalysts for Innovation and Quality in Higher Education. Procedia Economics and Finance, 23(October 2014), 704-711. https://doi.org/10.1016/s2212-5671(15)00409-8.

Rinaldi, L., Cho, C. H., Lodhia, S. K., Michelon, G., \& Tilt, C. A. (2020). Accounting in times of the CoVID-19 pandemic: a forum for academic research. Accounting Forum, O(0), 1-4. https://doi.org/10.1080/01559982.2020.1778873.

Ritter, T., \& Pedersen, C. L. (2020). Analyzing the impact of the coronavirus crisis on business models. Industrial Marketing Management, 88(May), 214-224. https://doi.org/10.1016/j.indmarman.2020.05.014.

Shin, D. H. (2009). An empirical investigation of a modified technology acceptance model of IPTV. $\begin{array}{llll}\text { Behaviour and Information Technology, 28(4), 361-372. } & \end{array}$ https://doi.org/10.1080/01449290701814232.

Smith, D. E., \& Mitry, D. J. (2008). Investigation of Higher Education: The Real Costs and Quality of Online

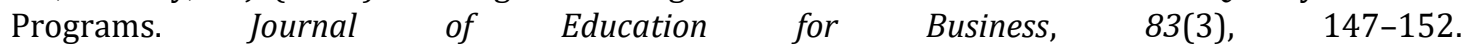
https://doi.org/10.3200/JOEB.83.3.147-152.

Sun, P. C., Tsai, R. J., Finger, G., Chen, Y. Y., \& Yeh, D. (2008). What drives a successful e-Learning? An empirical investigation of the critical factors influencing learner satisfaction. Computers and Education. https://doi.org/10.1016/j.compedu.2006.11.007.

Svendsen, G. B., Johnsen, J. A. K., Almås-Sørensen, L., \& Vittersø, J. (2013). Personality and technology acceptance: The influence of personality factors on the core constructs of the Technology Acceptance Model. Behaviour and Information Technology, 32(4), 323-334. https://doi.org/10.1080/0144929X.2011.553740.

Taherdoost, H. (2018). Development of an adoption model to assess user acceptance of e-service technology: E-Service Technology Acceptance Model. Behaviour and Information Technology, 37(2), 173-197. https://doi.org/10.1080/0144929X.2018.1427793.

Talebian, S., Mohammadi, H. M., \& Rezvanfar, A. (2014). Information and Communication Technology (ICT) in Higher Education: Advantages, Disadvantages, Conveniences and Limitations of Applying Elearning to Agricultural Students in Iran. Procedia - Social and Behavioral Sciences, 152, 300-305. https://doi.org/10.1016/j.sbspro.2014.09.199.

Teo, T. (2012). Examining the intention to use technology among pre-service teachers: An integration of 
the Technology Acceptance Model and Theory of Planned Behavior. Interactive Learning Environments, 20(1), 3-18. https://doi.org/10.1080/10494821003714632.

Venkatesh, V., Morris, M. G., Davis, G. B., \& Davis, F. D. (2003). User acceptance of information technology: Toward a unified view. MIS Quarterly: Management Information Systems. https://doi.org/10.2307/30036540.

Walker, Z., Kho, H. H., Tan, D., \& Lim, N. (2020). Practicum teachers' use of mobile technology as measured by the technology acceptance model. Asia Pacific Journal of Education, 40(2), 230-246. https://doi.org/10.1080/02188791.2019.1671808.

Wentzel, J. P., Diatha, K. S., \& Yadavalli, V. S. S. (2013). An application of the extended Technology Acceptance Model in understanding technology-enabled financial service adoption in South $\begin{array}{llll}\text { Africa. Development } & \text { Southern }\end{array}$ https://doi.org/10.1080/0376835X.2013.830963.

Xiangqian, L., \& Fuqing, G. (2012). Development-Driven E-learning Education Model and Application in Teaching Information Technology. IERI Procedia, 2, 854-858. https://doi.org/10.1016/j.ieri.2012.06.182.

Xue, E., Li, J., Li, T., \& Shang, W. (2020). How China's education responses to COVID-19: A perspective of policy analysis. Educational Philosophy and Theory, o(0), 1-13. https://doi.org/10.1080/00131857.2020.1793653. 